\title{
II. An abstract of the characters of Ochsenheimer's Genera of the Lepidoptera of Europe; with a list of the species of each genus, and reference to one or more of their respective icones
}

\author{
J.G. Children F.R.S. L. \& E. F.L.S.
}

To cite this article: J.G. Children F.R.S. L. \& E. F.L.S. (1829) II. An abstract of the characters of Ochsenheimer's Genera of the Lepidoptera of Europe; with a list of the species of each genus, and reference to one or more of their respective icones, Philosophical Magazine Series 2, 6:31, 9-16, DOI: 10.1080/14786442908675049

To link to this article: http://dx.doi.org/10.1080/14786442908675049

曲 Published online: 13 Jul 2009.

Submit your article to this journal ¿

Џll Article views: 2

Q View related articles $\square$ 
II. An Abstract of the Characters of Ochsenheimer's Genera of the Lepidoptera of Europe; with a List of the Species of each Genus, and Reference to one or more of their respective Icones. By J. G. Children, F.R.S. L. \& E. F.L.S. \&.c.

[Continued from vol. v. p. 370.]

Genus 53. MANIA, Ochs., Treitsch.

Monmo, Ochs. Lemures, Hübn.

Legs, gressorial; second and third pair with the tibice armed with long, stout spines, terminated by a very fine point.

Wings triangular, margins crenate.

Antenna filiform, pectinated; pectinations extremely short.

Body rather stout; thorax densely pilose; back with a separate

tuft of hair on each segment, except the last, forming a crest down the middle; abdomen terminated by a tuft of hairs.

Larva naked, with a small head; body tapering towards the hinder part ; the last segment tuberculated.

Obs. Mormo being a term already employed in ornithology, M. Treitschke has rejected it, and adopted that of Mania in its stead.

Species.

Icon.

1. Man. Maura, Lien.... Ernst, VIII. Pl. CCCXIX. f.561.

2. - Typica, Linn.*... Ernst, VII. Pl.CCLXXXI.f.461.

\section{Genus 54. HADENA, Schrank.}

Wings deflexed; body with tufts of hair on the back, forming a longitudinal crest; (as in the preceding genus;) posteriorly gibbous.

Larve various: Pupa subterranean. Treitschke has subdivided this genus into four families, founded (except the second) on certain markings on the anterior wings, not, however, sufficiently definite or constant to afford good

lines

* Nania, Steph.

" Palpi rather long, porrect, ascending, triarticulate, the two basal joints clothed with elongate capitate scales, terminating in an acute point anteriorly, at the apex of the second joint, apical joint slender, elongate, exposed, covered with abbreviated scales; basal joint of equal length with the terminal, and slightly bent, the second nearly as long again, more slender than the first, a little attenuated at the apex; terminal linear, very slender, slightly acuminated: maxille longer than the antennæ. Antenna short, slender in the females, ciliated internally

N. S. Vol. 6. No. 31. July 1829. 
lines of demarcation between the respective groups. They are briefly as follows :

FaM. A. With fine lines and transverse bands of a light colour on the anterior wings.

B. The males with strongly pectinated antennæ.

C. The anterior wings with an indented transverse band near the outer margin, and irregular oblong or reniform spots between the indented band and the base of the wing.

D. The anterior wings with light-coloured transverse fasciæ, and a conical spot, extending from the base of the wings nearly to the second cross band.

Fam. A. Species.

Icon.

1. H. Saponarice, Hübn. Ernst, VII.Pl.CCLXXXI. f.462.

2. - Perplexa, Hübn. Ernst, VII. Pl.CCXC.f.488. c.d.

3. - Capsincola, Hübn. Ernst, VII. Pl. CCLXXX.f. 460.

4. - Cucubali, Hübn. Ernst, VII. Pl.CCLXXXI.f.463.

Fam. B.

5. H. Popularis, Fab.... Ernst, V.Pl. CLXXXVII. f. 243. 244 .

6. - Leucophrea, Hübn. Ernst, V. PI.CLXXXVIII. f.245. Fam. C.

7. H. Glauca, Hübn.... Hübn. Noct. Tab. 87.f.410.(fom.)

8. - Proxima, Huibn. Hübn. Noct. Tab. 87.f.409. (fœm.)

9. - Marmorosa, Bork. Ernst, VI. Pl.CCXXXVII.f.348.

10. - Dentina, Hübn... Ernst, VI. PI. CCXLII. f. 356.

11. - Peregrina, Treitsch.*

FAM. D.

12. H. Amica, Treitsch.†

in the males: head small, with a crest between the antennæ: eyes rather prominent, naked: thorax stout, with an anterior and posterior crest : abdomen slightly depressed, with a carina in the male : wings incumbent, faintly denticulate: legs short, rather stout. Larva naked, with the anal segment a little elevated: pupa folliculated, with a single spine at the apex."-Steph. Illust. Brit. Ent. Haustell. II. 165.

Stephens complains of the unnatural union of the Noctuæ Maura and Typica, Linn. effected by Ochsenheimer and 'Treitschke, "than which," he says, "nothing can be more unnatural, their only resemblance consisting in the dinginess of their colours."- "Nænia may be readily known by the peculiar bifid appearance of the apex of the palpi, arising from the elonga* tion of the scales,-combined with the highly crested thorax, dingy, reticulated, and subcrenated wings."-Steph. l.c.

* Had. alis anticis argillaceis, maculâ conicâ obscuriori, strigâ posticâ dentatâ albidâ, maculis sagittiformibus brunneis; posticis albis, fusco venosis.-Treitschke.

+ Had. alis anticis fusco rubroque variis, maculâ anteriori oblongâ, reniformique albidis, fasciầ posticâ violaceâ. 
Species.

Icon.

13. H. Satura, Hübn..... Ernst, VII. Pl. CCLXXXVI. f. 475 . b. c.

14. - Adusta, Hübn. ... Ernst, VII. Pl. CCLXXXVI. f. 476 . c.

15. - Thalassina, Borkh. Ernst, VII. Pl. CCLXXXVI. f. 4.74. a. b.

16. - Gemina, Hüln... Ernst,VII.Pl.CCLXXXV.f.471.

17. - Geniste, Hubn... Ernst,VII.PI.CCLXXXV.f.473.

18. - Contigua, Fab. ... Ernst,VII.Pl.CCLXXXV.f.472.

19. - Eruginea, Hübn. Ernst, VII. Pl. CCLXXXIX. f. 482 .

20. - Convergens, Fab. Hübn. Noct.Tab.18. f.84. (mas.)

21. - Distans, Hübn... Hübn.Noct.Tab.112.f.522.(mas.) 523. (fœm.)

22. - Protea, Hübn. ... Hübn. Noct.Tab. 87.f.406. (mas.)

\section{Genus 55. ERIOPUS*, Treitsch:}

Legs, anterior pair porrected when at rest, in the males furnished with long woolly hairs, as far as the penultimate joint of the tarsus; in the females naked.

Antennce slightly pectinated on the inner side, in the males, rather pubescent beneath; simple in the females.

Wings, anterior deflexed, angular.

Larva solitary, feeds on the Pteris aquilina (Common Fern) and always keeps underneath the leaves; head light-brown or fulvous; body delicate green, with a white stripe, margined with brown on the sides and stigmata, and a transverse line and a crescent of the same colours on each segment, the points of the crescent being directed towards the anus. Duponch. Lep. de France, vi. 326.

Pupa subterranean. Id. l.c.

Esper had named the species on which Treitschke has formed this genus Lagopus; but as that term is already adopted in Ornithology, the latter has changed the appellation to Eriopus.

Species.

Icon.

1. Eri. Pteridis, Huibn. Hübn. Noct. Tab.13. f. 65. (fœm.) Larv. Lepid. IV. Noct. II. Genuin. E. e. fig. a. b. Duponch. VI. pl. 93. fig. 1. (mas.)

The only species of the genus.

$$
\text { fig. 2. (fœm.) }
$$

* Egrov lana, $\pi 00$ s pes-woolly foot.

C 2

Genus 
Genus 56. PHLOGOPHORA*, Treitsch.

Antennce long, setaceous, slightly pectinated on the inner side. Wings indented; anterior rounded or angular, generally variegated with brilliant colours.

Body, thorax crested.

Larva rather long and slender, with a small tubercle on the anal segment; delicately marked with longitudinal and transverse lines; feeds chiefly on low plants.

Pupa folliculated; metamorphosis subterranean.

FAM. A.-Wings involuted when at rest, crenate; the anterior marked with brilliant colours.

FAM. B.-Wings rounded, less involuted, subdeflexed; only the cilia crenate.

Fam. A. Species. Icon.

1. Phl. Adulatrix, Hübn. Hübn. Noct. Tab. 111. fig. 517. (fom.) Tab. 142. fig. 649. 650. (mas.)

2. - Scita, Hübn...... Hübn. Noct.Tab. 14. fig.68.(fœm.) Tab. 101. fig. 475. (mas.)

3. - Meticulosa, Linn. Ernst, VII. PI. CCXC. f. 487. FaM. B.

4. Phl. Lucipara, Linn... Ernst, VII. Pl. CCXCII. f. 491.

5. - Fovea, Treitsch.†

6. - Empyrea, Hübn. Ernst, VII. Pl. CCLXVII. f.426.

Genus 57. MISELIA $\ddagger$, Treitsch. (Curtis.)

Miseli e, Hübn.

Antenna inserted close to the eyes, on the crown of the head, long, setaceous, robust in the males, sometimes produced on the inside; covered with scales above, pubescent beneath, basal joint cup-shaped, the scales extending far beyond the edge.

Maxille spiral, setaceous, not longer than the antennæ, furnished with tentacula at the apex.

Labial palpi short, porrected somewhat obliquely, thickly clothed with scales excepting the terminal joint, which is almost naked; 3-jointed, basal joint rather robust, 2nd long and not so thick, 3rd elongate obovate.

* Фros famma, Qsgos fero.

+ Phl. alis anticis purpurascentibus lucidis, fasciâ nigrâ, stigmate postico maculâque marginis interioris flavis : posticis cinereis, foveâ pellucidâ in mare.-Ochs. Theilsch. V. pars I. p. 380.

f. Muss odio, Haros Sol. 
Ochsenheimer's Genera of the Lepidoptera of Europe. 13

Head tufted on the crown: eyes rather small and oval.

Body, thorax quadrate, thickly clothed with scales: abdomen large, robust, angulated, tufted on the back near the base, ovate conic in the females.

Wings slightly deflexed; superior large, the posterior margin and cilia crenate; inferior rather small.

Legs strong, anterior the shortest: femora thickly ciliated: tibia, anterior thickly clothed with scales, concealing the internal spine, middle and posterior spurred, the latter having a pair above the apex, one being very short: tarsi 5 -jointed, basal joint the longest, as long as the tibia in the anterior pair : clawes distinct, bifid: pulvilli small.

Larva, head and pectoral segments depressed, penultimate gibbous or tuberculated*.

Species.

Icon.

1. Mis. Conspersa, Hübn. Ernst, VI.Pl.CCXXX.f.332.c. g. 2. - Compta, Hübn.... Ernst, VI. Pl. CCXXX. f. 332. a. b.

3. - Albimacula, Borkh. Ernst, VI. PI. CCXXX. f. 331.

4. - Gemmea, Treitsch.†

5. - Culta, Fab........ Ernst, VI. Pl. CCXXIX. f. 329.

6. - Serpentina, Treitsch.†

7. - Oleagina, Fab.§... Ernst, V. Pl. CLXXXVI. f. 241.

8. - Orbiculosa, Esper. Esper. Schm. III. Th. Tab. 93. f. 8.

9. - Oxyacantha, Linn. Ernst, VI. PI. CCXXIX. f. 328. 10. - Bimaculosa, Linn. Ernst, VI. Pl. CCXXIX.f. 327. Curtis, Brit. Ent. IV. Pl. 177. Imago et Larva.

11. - Aprilina, Linn.... Ernst, VI. Pl.CCXXVIII. f. 326.

Genus 58. POLIA, Treitsch. (Curtis.)

Polız, Hübner.

Antennce inserted close to the eyes on the crown of the head, setaceous, rather stouter in the males, composed of nu-

* Characters from Curtis, Brit. Ent. IV. 177.

+ Mis. alis anticis fuscis flavo alboque variis, maculis ordinariis albis, lineisque transversis arcuatis atris; posticis cinereis, lunulâ mediâ fasciâque terminali fuscis.-Ochs. Treitsch. V. pars I. 393.

$\mp$ Mis. alis anticis viridescenti fuscis, nigro undatis, maculâ reniformi albâ; posticis maris niveis nigrocinctis, faminæe cinereo adspersis,-Ochs. Treitsch. V. pars I. 399.

$\$$ Curtis rejects this species, as incompatjble with the genus, on account of its strongly pectinated antenna. Fabricius classes it with the Bombyces.

merous 
merous transverse joints, covered with scales above, pubescent beneath, each joint producing a bristle.

Maxilla setaceous, spiral, not longer than the antennæ, furnished with tentacula at the apex.

Labial palpi porrected obliquely, thickly clothed with scales, which are longest beneath and very short on the terminal joint; triarticulate, basal joint short, slightly curved, 2nd twice as long, slightly attenuated, and acuminated at the superior angle of the apex, 3rd rigid, compressed, ovate and acuminated, having a longitudinal groove on the side.

Head thickly clothed with shortish scales: eyes globose : ocelli two.

Body, thorax subquadrate, slightly crested and trilobed : $a b$ domen long, robust, sometimes tufted down the back, obtuse, dilated at the apex in the males, somewhat tapering in the females.

Wings deflexed; anterior long, sublanceolate.

Legs strong, anterior the shortest: femora thickly ciliated: tibia, anterior thickly clothed with scales, concealing the internal spine, the others spurred, and furnished with a brush of scales on the outside near the middle, the posterior with two pair of unequal spurs: tarsi with the basal joint very long, having series of bristles beneath: clares bifid *.

Larva smooth, cylindrical, feeds on low plants.

Pupa folliculated; metamorphosis subterranean.

FAM. A.-General colour greyish white, the wings rather short, and rounded. Larva greenish, usually becoming greyish-brown before it changes to the pupa state.

Fam. B. - General colour brown, the wings longer. Larva dark coloured, dusky.

FaM. C. - Anterior wings rounded, and dark coloured; posterior yellow, with black margins. Larva whitishgray coloured.

Falm. A. Species. Icon.

1. Pol. Cappa, Hübn..... Hübn. Noct. Tab. 95. fig. 447. (fom.)

2. - Chi, Linn.......... Ernst, VI. Pl. CCXLI. f. 354 .

3. - Serena, Fab. ...... Ernst, VI.Pl.CCXL.f. 352. c-f

4. - Dysodea, Hübn... Ernst, VI. Pl.CCXXXIX.f.350. a-f.

5. - Filigrama, Esp... Ernst, VI.PI.CCXXXIX.f.350. $\mathrm{g}$-i.

* Characters from Curtis, Brit. Ent. VI. 248. 
Ochsenheimer's Genera of the Lepidoptera of Europe. $\quad 15$ Species.

Icon.

6. Pol. Casia, Hübn..... Ernst, VI. Pl. CCXLI. f. 355.

7. - Templi, Thunb... Hübn. Noct. Tab. 80. fig. 373. (mas.)

8. - Polymita, Linn... Ernst, VII. Pl. CCCLXXIII. f. 439 .

9. - Flavicincta, Fab... Ernst, VI. Pl. CCXXXVIII. f. 349 .

10. - Nigrocincta,Treitsch.*

11. - Platinea, Treitsch.†

FaM. B.

12. Pol. Zeta, Treitsch.

13. - Serratilinea, Treitsch. Hübn. Noct. Tab. 78. fig. 365. (mas.)

14. - Advena, Fab...... Ernst, VII. Pl. CCLXXXIV. fig. 468.

15. - Tincta, Borkh. ... Ernst, VII. Pl. CCLXXXIII. fig. 467.

16. - Nebulosa, Hübn. Ernst, VII. Pl. CCLXXXIV. f. 470 .

17. - Occulta, Linn.... Ernst, VI.Pl.CCXXXII.fig. 336. Curtis, Brit. Ent. Pl. 248. Larva et Imago.

18. - Herbida, Hübn... Ernst, VII. Pl. CCLXXXII. FaM. C. fig. 465 .

19. Pol. Prospicua, Hübn, Ernst, VII. Pl. CCLXVIII. fig. 431.

20. - Textaई, Esp....... Ernst, VII. Pl. CCLXVIII. fig. 430.

Genus 59. TRACHEA, Treitsch. Achatize, Hübner. (Achatea, Curtis.)

Wings deflexed, anterior usually variegated with lively colours; posterior ciliated; cilia generally white, or very light coloured.

Body

* Pol. alis anticis cinerascentibus, medio nigrocinctis, strigâque posticâ albis.-Ochs. Treitsch. V. pars I. 31.

+ Pol. alis anticis albido-griseis splendentibus, strigis cinerascentibus obsoletis, serie punctorum nigrorum ad marginem externum.-Ochs.Treitsch.V. pars I. 34.

$\ddagger$ Pol. alis anticis cæruleo-cinereis, 2 . albo notatis, funbriis latioribus albo cinereoque variis.-Ochs. Treitsch. V. pars I. 35.

$\$$ Cenigo, Steph.

"Palpi rather porrect, ascending, slightly compressed, clothed with loose hair-like scales, triarticulate, the joints of nearly equal length, the 
Body, thorax crested, crest divided, small.

Larva, marked with broad, longitudinal bands, generally of brilliant colours. Metamorphosis subterranean.

FAM. A.-Wings broad and long.

FAM. B.-Wings narrow and long.

F⿳M. C. - Wings broad and short.

Fam. A. Species. Icon.

1. Tr. Atriplicis, Linn... Ernst, VII. PI. CCLXXXII. Fam. B.

2. Tr. Pracox, Linn..... Ernst, VII. Pl. CCLXXXIII.

FaM. C.

3. Tr. Porphyrea, Hübn. Ernst, VI.Pl.CCXXXV.fig.340. 4. - Piniperda*, Esper. Ernst, VII. Pl. CCXCI. fig. 489. Curtis, Brit. Ent. III. Pl. 117. Larva et Imago.

basal joint reniform, the next cylindric, slightly attenuated at the apex, the terminal more slender, bending outwards, and somewhat acute: maxille long. Antennce elongate, setaceous, slightly pectinated to the apex in the males: head clothed with loose scales: thorax stout, a little crested behind, loosely squamous: body cylindric, rather long, slightly carinated on the back, tufted at the apex: wings horizontal, entire, anterior elongate-triangular, with three stigmata: posterior suborbiculate-triangular, usually pale yellow, with a darker hinder border."-Steph. Illust. Brit. Ent. Haust. II. p. 106.

Stephens considers this species as more allied in its habits to the Triphænæ than the Polia, from the latter of which it is readily known by its proportionately shorter and broader (anterior) wings, and by the lively colour of the posterior; and from the former it differs in the proportion of the joints of its palpi, its suberested thorax, and dissimilar antennæ. Stephens mentions no other species as belonging to this genus.

* Achatea, Curtis.

"Antennce inserted at the back of the head, serrated, and somewhat thickest in the middle in the males, slender in the females, composed of numerous joints, covered with scales above, hairy beneath, the basal joint large and hairy.

"Maxilla long, furnished with tentacula towards the apex.

“ Labial palpi small, very hairy, porrected horizontally, 3-jointed, 1st joint curved upward, long, robust, 2nd short robust, attenuated, 3rd minute, cylindric, truncate.

" Head small, nearly concealed : eyes small. Thorax large, hairy : abdomen robust, short, very soft, hairy beneath. Wings deflexed when at rest; superior obtuse, inferior rather small. Legs, anterior short: tibice, anterior short with a small spine on the internal side, 4 posterior terminated by spurs : tarsi 5-jointed : claws large. Larva naked, with 6 pectoral, 8 abdominal, and 2 anal feet." -Curtis, $l$. $c$.

[To be continued.] 